\title{
Shapiro-szindróma, azaz a termoregulációs zavar ritka esete
}

\author{
Szabó Júlia dr. ${ }^{1}$ - Zádori Dénes dr. ${ }^{2}$ \\ Varga Edina Tímea dr. ${ }^{2}$ - Vécsei László dr. ${ }^{2,3}$
}

'Jász-Nagykun-Szolnok Megyei Hetényi Géza Kórház-Rendelőintézet, Neurológiai Osztály, Szolnok ${ }^{2}$ Szegedi Tudományegyetem, Általános Orvostudományi Kar, Szent-Györgyi Albert Klinikai Központ, Neurológiai Klinika, Szeged

${ }^{3}$ MTA-SZTE Idegtudományi Kutatócsoport, Szeged

\begin{abstract}
A corpus callosum anomáliái a központi idegrendszer leggyakoribb fejlődési rendellenességei. A corpus callosum agenesiához társuló spontán periodikus hypothermia és hyperhidrosis triászt Shapiro-szindrómának nevezték el. A Shapiro-szindróma ritka kórkép, amely bármilyen életkorban megjelenhet. A corpus callosum agenesia nem megkülönböztető jegye a szindrómának, mint azt korábban feltételezték, a paroxysmalis hypothermia bizonyult a fő betegségjegynek. A rekurrens hypothermia hátterében a maghőmérséklet beállításáért felelős hypothalamus múködési zavarát feltételezik, de a pontos patofiziológia még nem ismert. Definitív terápia nem létezik, az életminőséget viszont kedvezően befolyásoló szupportív terápiás alternatívák állnak rendelkezésre. A szerzők az esetismertetésben az első, hazánkban diagnosztizált Shapiro-szindrómás beteget mutatják be. A 21 éves férfi beteg fó tünete a rekurrens hyperhidrosis és hypothermia, következményes elesett általános állapot volt. A koponya mágneses rezonanciás vizsgálata corpus callosum agenesiát igazolt. A betegnél az empirikusan indított clonidinterápia hatásosnak bizonyult, s mint számos korábban közölt esetben, a klinikai tünetek remissziója jelentkezett. Orv. Hetil., 2016, 157(7), $275-278$.
\end{abstract}

Kulcsszavak: corpus callosum agenesia, Shapiro-szindróma, termoregulációs zavar

\section{A rare case of thermoregulation disorder: Shapiro syndrome}

\begin{abstract}
Anomalies of the corpus callosum are the most frequent malformations of the central nervous system. The triad of spontaneous periodic hypothermia and hyperhydrosis with the agenesis of corpus callosum is described as Shapiro syndrome. Shapiro syndrome is a very rare condition and it can occur in every age group. The presence of agenesis of corpus callosum is not a strict criteria of the syndrome; the most important presenting symptom is paroxysmal hypothermia. Although the definite cause of recurrent hypothermia is unknown, dysfunction of the hypothalamus is suspected. From therapeutic aspects, only supportive therapy is available. In this report the authors present the first Shapiro syndrome case diagnosed in Hungary. The main symptoms of the 21-year-old male patient were recurrent hyperhydrosis with hypothermia resulting in severe general malaise. The skull magnetic resonance imaging demonstrated agenesis of corpus callosum. The patient was treated with clonidine resulting in significant improvement of symptoms.
\end{abstract}

Keywords: corpus callosum agenesis, Shapiro syndrome, thermoregulation disorder

Szabó, J., Zádori, D., Varga, E. T., Vécsei, L. [A rare case of thermoregulation disorder: Shapiro syndrome]. Orv. Hetil., 2016, 157(7), 275-278.

(Beérkezett: 2015. november 26.; elfogadva: 2015. december 14.)

\section{Rövidítések}

ACC $=$ corpus callosum agenesia; SS = Shapiro-szindróma

A corpus callosum anomáliái a központi idegrendszer leggyakoribb fejlődési rendellenességei. Az élveszületési prevalencia a dél-alföldi régióban 2,05/10 000 (1992. július 1.-2006. június 30.), hasonló a más országokból közölt adatokhoz [1]. Az esetek többségében kimutatott a motoros és intellektuális fejlődés késlekedése [1]. 1969-ben William Shapiro és Plum írta le először a corpus callosum agenesiához társuló spontán periodikus hypothermia és hyperhidrosis triászt, a Shapiro-szindrómát (SS). Az SS egy ritka kórkép, amely bármilyen élet- 
korban megjelenhet. A rendelkezésre álló szakirodalmi adatok szerint eddig 52 esetet publikáltak. 1994-ben Hirayama és mtsai közölték az első reverz SS-t, amelyet a corpus callosum agenesiához (ACC) társuló spontán periodikus hyperthermia jellemez. 2013-ban egy 3,5 éves kislánynál került először leírásra ACC-hez társuló periodikus hypothermia és hyperthermia egyaránt, amely alapján a Shapiro- és reverz Shapiro-szindrómát már nem tartják különálló entitásnak [2]. ACC nélkül megjelenő SS fenotípust variáns SS formának nevezi az irodalom. ACC csak az esetek 40\%-ában igazolódott, ami arra utal, hogy az ACC nem megkülönböztető jegye az SSnek, mint azt korábban feltételezték, így az ok-okozati összefüggés nem bizonyított. Ezt támogatja az a tény is, hogy még soha nem írtak le callosotomia után jelentkező epizodikus hyperhidrosist és hypothermiát [3]. A hyperhidrosis is csak az esetek 42,3\%-ában jelentkezett, túlnyomóan felnőttkori kezdet esetén [4]. A klinikai jelek közül a paroxysmalis hypothermia bizonyult a fó betegségjegynek mind a hagyományos, mind a variáns SS esetében, amely óráktól évekig is elhúzódhat; felismerése fontos a korai diagnózis felállításához [4]. A rekurrens hypothermia hátterében a maghőmérséklet beállításáért felelős hypothalamus múködési zavarát feltételezik, de a pontos patofiziológia még nem ismert. Az SS ritka elöfordulása, állatkísérletek és kontrollcsoport hiánya miatt definitív terápia nem létezik, az életminőséget viszont kedvezően befolyásoló szupportív terápiás alternatívák rendelkezésre állnak. Esetismertetésünkben az első, hazánkban diagnosztizált SS-beteget mutatjuk be.

\section{Esetismertetés}

A 21 éves férfi beteg 2013 szeptemberében került felvételre a Szegedi Tudományegyetem, Neurológiai Klinikára háromhetes panaszkörrel, részletes infektológiai és endokrinológiai kivizsgálását követően. A beteg naponta többször, akár 60 percig is elhúzódó kifejezett verejtékezést panaszolt testszerte, amelyet erőteljes hidegrázás követett. Napszaki ingadozást nem tapasztalt, alvás közben és éber állapotban panaszai egyaránt jelentkeztek, azokat kiváltó külső tényezővel nem lehetett összefüggésbe hozni. Az epizódok között fél-egy órás panaszmentes időszakok voltak. Az alapellátását végző területileg illetékes kórházban kóros testhőmérsékletet nem regisztráltak. A tünetek kezdete óta az addig fizikailag aktív férfi oly mértékben kimerült, hogy ágyhoz kötötté vált, az erőtlenség miatt egész nap csak feküdt. Csökkent az érdeklődése, kezdeményezési készsége, majd alvászavar jelentkezett, étvágytalanná vált, három hét alatt $8 \mathrm{~kg}$ ot fogyott. Praecollaptiform rosszullétekről és gyakori szívdobogásérzésról számolt be, az ürített vizelet menynyisége csökkent (körülbelül $500 \mathrm{ml} / 24$ h). Távolabbi anamnézisében hatéves korában diagnosztizált empty sella szindróma, növekedésbeli elmaradás miatt átmeneti növekedésihormon-pótlás, enyhe fokú mentális retardáció (IQ: 71) szerepelt, egyebekben krónikus betegség nem volt ismert. Görcstevékenységről és fejtraumáról nincs adat. A beteg gyógyszert nem szedett rendszeresen, belgyógyászati és családi anamnézise releváns adatot nem szolgáltatott, testvére nincs. Felvételi belgyógyászati státuszából kiemelendő adatok: letargia, sápadt színezetű bőr, craniofacialis dysmorphia (távol álló szemek, széles orrgyök, micrognathia). Vitális paraméterei ülve, nyugalomban: bradycardia (46 ütés/perc), normotensio (105/65 Hgmm), normoglykaemia $(5,2 \mathrm{mmol} / \mathrm{l})$, $35,9^{\circ} \mathrm{C}$ axillaris testhőmérséklet, $19 \mathrm{~kg} / \mathrm{m}^{2} \mathrm{BMI}$. Neurológiai státusz vonatkozásában csak a vegetatívum részéről észleltünk kórosat, testszerte jelentkező kifejezett, meleg verejtékezés formájában. Hozott részletes laboratóriumi vizsgálat (rutin vérkép és biokémia, részletes hormonpanel, vizelet- és széklettenyésztés, HIV-szerológia), tuberkulin-bőrpróba, has- és kismedencei ultrahang, mellkas-röntgenvizsgálat kórosat nem mutatott. A kontroll felvételi fizikális és laboratóriumi vizsgálat gyulladásra utaló eltérést nem igazolt. Az előzményeket figyelembe véve központi idegrendszeri eredetet feltételezve sürgős kontrasztos koponya-MR-vizsgálat történt, amely corpus callosum agenesiát és kisagyi atrophiát igazolt (1. ábra). A tág oldalkamrákra tekintettel idegsebészeti véleményezést kértünk, amely szerint hydrocephalusra utaló nyomási tünetek hiányában a beteg akut idegsebészeti teendőt nem igényelt. Rutin liqordiagnosztikai vizsgálat negatív eredménnyel zárult.

Az első napokban átlagosan 8-10 alkalommal észleltünk random módon, testszerte jelentkező, akár fél órán át elhúzódó kifejezett verejtékezést, amelyet heves hidegrázás és letargia követett, majd spontán javulás. A hyperhidrosis ideje alatt kezdetben mérési technikai hibának tartott, majd ismételt mérésekkel megerősített hypothermia tartományba eső $\left(<35^{\circ} \mathrm{C}\right)$ axillaris testhőmérséklet-értékeket (digitális hőmérővel) regisztráltunk. Hyperhidrosis időszakában 32,4-33,9 ${ }^{\circ} \mathrm{C}$ közötti testhőmérséklet-tartományt, a hidegrázás ideje alatt 34,7$34,9^{\circ} \mathrm{C}$, panaszmentes időszakban $34,9-35,4{ }^{\circ} \mathrm{C}$ közötti értékeket mértünk. $\mathrm{Az}$ epizódok alatt a beteg hypotoniás (80-85/45-50 Hgmm) és bradycard (45$50 /$ perc), valamint normoglykaemiás volt. Eszméletvesztést, görcstevékenységet nem észleltünk. A megfigyelés, kivizsgálás időszakában erélyes folyadékpótlást és roborálást indítottunk tekintettel a jelentős folyadék- és elektrolitvesztésre. A meleg takarót a beteg nem tolerálta a hyperhidrosis ideje alatt. Rutin- és „ictalis” EEG-vizsgálat diffúz lassulást mutatott, epilepsziás múködészavar jelei nélkül. A spontán rekurrens hypothermia, hyperhidrosis és corpus callosum agenesia triász alapján a Shapiro-szindróma teoretikus diagnózist állítottuk fel.

A szakirodalomban közölt eseteket figyelembe véve ex juvantibus clonidinterápiát indítottunk. A felépített $3 \times 150 \mu$ g terápiás dózis (testtömeg $62 \mathrm{~kg}$ ) mellett öt nap elteltével jelentős állapotjavulást tapasztaltunk. A hyperhidrosissal járó rosszullétek megritkultak, napi egy-két alkalommal jelentkeztek, tartamuk megrövidült. A beteg átlag-testhőmérséklete $36{ }^{\circ} \mathrm{C}$-ra emelkedett, a fizikai 

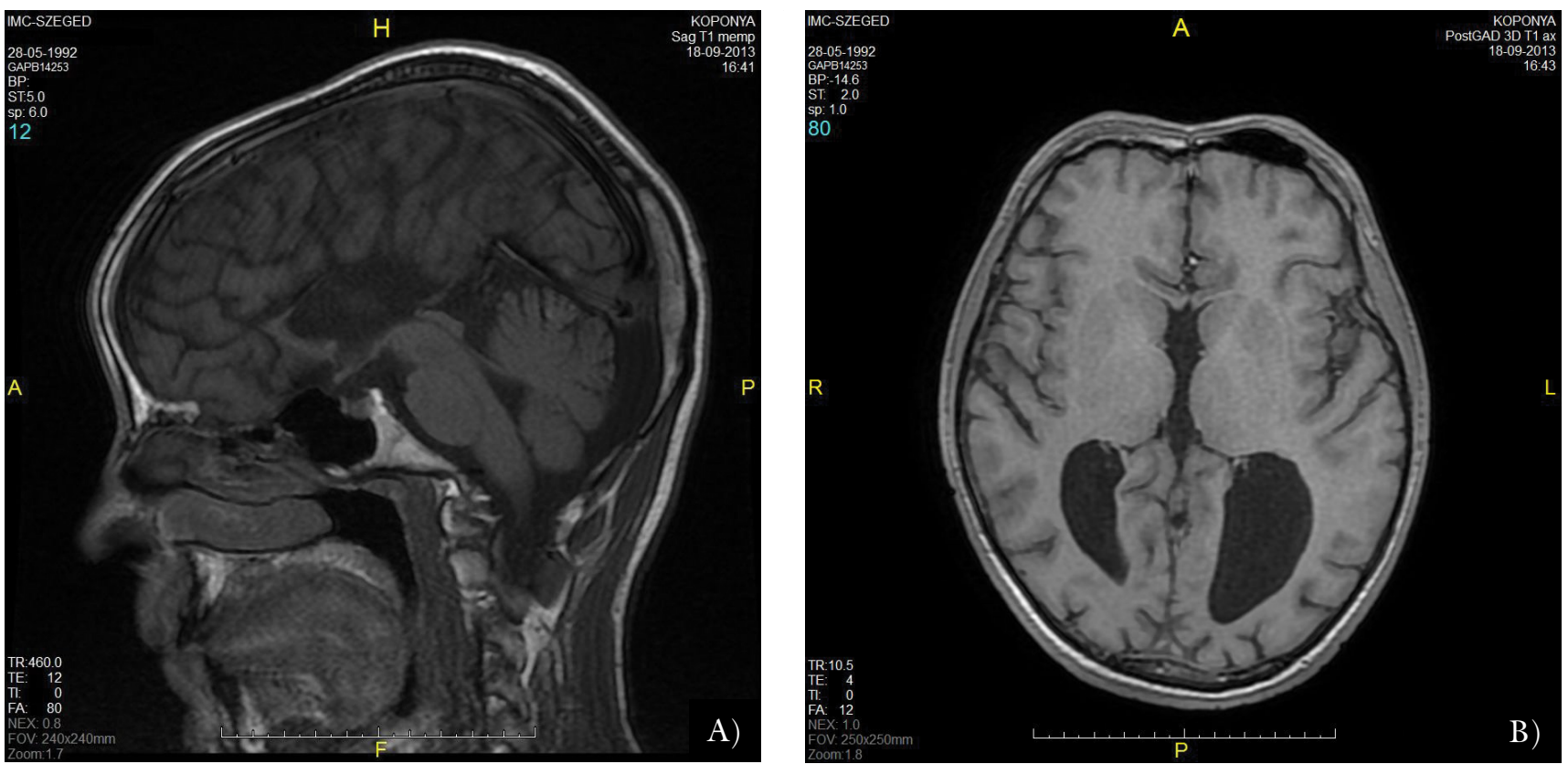

1. ábra

A 21 éves férfi betegnél készült MRI-felvételen (1,5 Tesla) corpus callosum agenesia (ACC) (A), következményes kamratágulat (A) (B), a gyrusok napsugárszerú elrendeződése (A), csökevényes elülső oldalkamraszarvak (B), aszimmetrikus hátsó oldalkamraszarvak (B), kisagyi atrophia (A) azonosítható. A: Tl-súlyozott sagittalis, B: Tl-súlyozott axiális

erőnléte javult, étvágya nőtt, érdeklődővé vált a környezete iránt. Fokozatosan mobilizáltuk, majd kielégítő általános állapotban bocsátottuk otthonába. Kezdetben háromhavonta jelentkezett kontrollvizsgálatra. Visszatérő enyhe rosszullétek miatt átmenetileg 450-0-600 $\mu \mathrm{g}$-ra emeltük a napi clonidindózisát (maximális megengedett napi dózis 2,4 mg), amely mellett állapotjavulás következett be, de mellékhatásként alvászavar, törzsön exanthema és vérnyomás-ingadozás jelentkezett. Kardiológiai vizsgálat során organikus eltérés nem igazolódott, alacsony vérnyomásértékeit clonidin-mellékhatásnak tulajdonították. Alvászavar és alacsony alaphangulat miatt pszichiáter szakorvos szelektív szerotonin-újrafelvételt gátló szert (sertralin reggel $50 \mathrm{mg}$ ) és alprazolamterápiát $(0,25 \mathrm{mg}-0,25 \mathrm{mg}-0,5 \mathrm{mg})$ indított, pozitív eredménynyel. A jelentkező mellékhatások miatt a clonidin napi dózisát $2 \times 300 \mu \mathrm{g}$-ra redukáltuk, amely mellett sporadikus, pár percig tartó hyperhidrosissal járó rosszullétekről számolt be a beteg. Állapotát kielégítőnek tartotta, a korábbi fizikai aktivitásához vissza tudott térni. 2014 decemberében volt legutóbb kontrollvizsgálaton, a koponya-MR az előző vizsgálathoz képest változást nem mutatott, állapota stagnál, a $2 \times 300 \mu \mathrm{g}$ clonidinterápiát jól tolerálja, egyéves kontrollvizsgálata esedékes.

\section{Megbeszélés}

A közölt eset teljesíti a hagyományos Shapiro-szindróma kritériumait, amely a spontán rekurrens hypothermia, hyperhidrosis és corpus callosum agenesia együttes fennállásán alapul. Az eset felhívja a figyelmet a pontos anamnézis és betegágy melletti szoros megfigyelés fontossá- gára, amely a jelen képalkotói diagnosztika vezérelte medicinában teret vesztett. Javasolt infektológiai és endokrin kórok kizárása. Differenciáldiagnosztikai szempontból megkönnyíti az elkülönítést a hyperthermiát okozó kórfolyamatok spektrumától (fertőző és nem fertőző betegségek) az a klinikai megfigyelés, hogy a hagyományos SS-sel ellentétben a citokinek hatására először jelentkezik a hidegrázás (következményes hyperthermia), majd azt követi az izzadás. Reverz SS esetén körülményesebb a diagnózis felállítása. Az SS patofiziológiája egyelöre nem ismert, a termoregulációs zavar hátterében egyik hipotézis szerint a szervezet termosztát szerepét betöltó hypothalamus paroxysmalis múködészavara állhat. Az alacsonyabb céltartományra (reverz SS esetén magasabb céltartomány) átállított maghőmérséklet elérése érdekében az SS-es beteg profúzan iz$\operatorname{zad}[5]$.

Az a megfigyelés, hogy az érintettek képesek lázzal reagálni fertőző megbetegedés esetén és képesek normothermiát fenntartani alacsony környezeti hőmérséklet mellett, arra utal, hogy a primer kórok nem lehet a hypothalamus célmaghőmérséklet átállítása [6]. A termoreguláció nem köthető egy körülírt központhoz, a hypothalamus, limbicus rendszer, agytörzs, gerincvelő és szimpatikus ganglionok közötti bonyolult neuronhálózaton alapul [7]. A periodikus termoregulációs zavar hátterében genetikai, degeneratív, traumás eredet, neurokémiai diszfunkció, diencephalicus epilepszia, alvászavar, intrauterin gyulladás (toxoplasmosis), toxikus hatás szerepe egyaránt felmerül. Egy esetben jelentettek familiáris halmozódást különböző nemű testvérpárnál, amely autoszomális recesszív öröklődésmenetre utalhat [4]. 
Leírtak karakterisztikus epigastrialis diszkomfortérzésként jellemezhető aurajelenséget is [8]. Gyermekeknél gyakran igazolódott SS és centrális endokrin zavar együttes fennállása [9]. Egy esetben írták le a ciklikus bicitopenia és SS okozta intrinszik ciklikus hypothermia közötti összefüggést [10]. Egy esetben vizsgáltak funkcionális képalkotó vizsgálattal hagyományos SS kritériumait teljesítő beteget. FDG-PET ( ${ }^{18}$ F-fluoro-deoxiglucose positron emission tomography) vizsgálattal a mesencephalon lamina tectalis, híd és agytörzs hátsó részén és a vermis felső szélén igazolódott hipermetabolizmus szimptómás fázisban, amely nem kizárt, hogy már egy kompenzatorikus válasz a testhőmérséklet-csökkenésre [11].

Definitív terápia egyelőre nem létezik, de a közölt esetekben számos centrális hatású, neurotranszmitterek hatását mímelő gyógyszer (dopaminantagonista - chlorpromazin hydrochlorid, haloperidol; reverz SS esetén dopaminagonista - levodopa és carbidopa, bromocriptin mesylat; szerotoninantagonista - cyproheptadin hydrochlorid; $\alpha 2$-adrenerg-agonista - clonidin, antiepileptikumok - carbamazepin, oxcarbazepin, levetiracetam, valproát) vagy a sympatectomia került kipróbálásra a periodikus hypothermia és hyperthermia befolyásolása céljából, változó eredménnyel. Egy esetben lépett fel spontán remisszió [4]. Egy hasonló kórlefolyású 21 éves nőbetegnél a levetiracetamterápia $(2 \times 1000 \mathrm{mg} /$ nap dózis) hatástalansága és negatív „ictalis” EEG miatt elvetették az epileptogén eredet lehetőségét [6]. Betegünknél az empirikusan indított clonidinterápia hatásosnak bizonyult, mint számos korábban közölt esetben, a klinikai tünetek remissziója jelentkezett.

\section{Következtetés}

A spontán hypothermia szokatlan klinikai tünet. Periodikus hyperhidrosis és hypothermia esetén gondolni kell a Shapiro-szindrómára vagy variáns formára. Fontos a korai diagnózis, ugyanis számos szupportív terápiás alternatíva áll rendelkezésre az életminőség javítására.

Anyagi támogatás: A kézirat összeállítását az MTASZTE Idegtudományi Kutatócsoport és a Nemzeti Agykutatási Program - KTIA_13_NAP-A-II/17. - támogatta.
Szerzői munkamegosztás: Sz. J.: Vizsgálatok lefolytatása, az irodalom áttekintése, a kézirat összeállítása. Z. D.: A közölt szindróma felismerése, a kézirat összeállításában nyújtott segítség. V. E. T.: A vizsgálatok koordinálása, a beteg követése, a kézirat összeállításában nyújtott segítség. V. L.: A kézirat összeállításában nyújtott segítség. A cikk végleges változatát a szerzők elolvasták és jóváhagyták.

Érdekeltségek: A szerzőknek nincsenek érdekeltségeik.

\section{Irodalom}

[1] Szabó, N., Sztriba, L.: Epidemiology of central nervous system malformations in South-Eastern Hungary. PhD Thesis. [A központi idegrendszer fejlődési rendellenességeinek epidemiológiája Délkelet-Magyarországon. PhD-értekezés.] Szeged, 2012. http://doktori.bibl.u-szeged.hu/1485/[Hungarian]

[2] Topcu, Y., Bayram, E., Karaoglu, P., et al.: The combination of thermal dysregulation and agenesis of corpus callosum: Shapiro's or/and reverse Shapiro's syndrome. Ann. Indian Acad. Neurol., 2013, 16(4), 716-719.

[3] Wabl, M., Strominger, Z., Jeremy, R. J., et al.: Variability of homotopic and heterotopic callosal connectivity in partial agenesis of the corpus callosum: a $3 \mathrm{~T}$ diffusion tensor imaging and Q-ball tractography study. Am. J. Neuroradiol., 2009, 30(2), 282-289.

[4] Tambasco, N., Belcastro, V., Prontera, P., et al.: Shapiro's syndrome: Defining the clinical spectrum of the spontaneous paroxysmal hypothermia syndrome. Eur. J. Paediatr. Neurol., 2014, $18(4), 453-457$.

[5] Chacha, M. J., Bernard, O., Keatlaretse, S., et al.: A case of Shapiro's syndrome in an African young man. Case Rep. Int. Med., $2015,2(2), 72-75$.

[6] Sheth, R. D., Barron, T. F., Hartlage, P. L., et al.: Episodic spontaneous hypothermia with hyperhidrosis: implications for pathogenesis. Pediatr. Neurol., 1994, 10(1), 58-60.

[7] Belcastro, V., Striano, P., Pierguidi, L., et al.: Recurrent hypothermia with hyperhidrosis in two siblings: familial Shapiro syndrome variant. J. Neurol., 2012, 259(4), 756-758.

[8] Mehta, S., Ralot, T., Masatkar, V., et al.: A curious case of hourly attacks of disabling episodic spontaneous hypothermia with hyperhidrosis. Indian J. Dermatol. Venereol. Leprol., 2015, 81(2), 185-186.

[9] Arkader, R., Takeuchi, C. A.: Shapiro syndrome with hypothalamic hypothyroidism. Arq. Neuropsiquiatr., 2008, 66(2B), 418-419.

[10] Roeker, L. E., Gupta, V., Gonsalves, W. I., et al.: Cyclic bicytopenia in a patient with Shapiro dyndrome. Case Rep. Hematol., 2013, 2013, ID 231713.

[11] Pazderska, A., O'Connell, M., Pender, N., et al.: Insights into thermoregulation: A clinico-radiological description of Shapiro syndrome. J. Neurol. Sci., 2013, 329(1-2), 66-68.

(Vécsei László dr., Szeged, Semmelweis u. 6., V. emelet, 6725 e-mail: vecsei.laszlo@med.u-szeged.hu) 